\title{
Hypokalemia results of treatment for patients in peritoneal dialysis with spironolactone
}

\author{
César A. Restrepo Valencia ${ }^{1}$, Gilberto Manjarrés Iglesias ${ }^{1-2}$, Consuelo Vélez Álvarez ${ }^{3}$ \\ ${ }^{1}$ Associate Professor of Caldas University
${ }^{2}$ Profesor Asistente, Universidad de Caldas \\ 3 Doctor of Public Health Caldas University
}

\begin{abstract}
Objective: To determine whether a treatment with spironolactone can correct chronic idiopathic hypokalemia for patients with chronic kidney disease undergoing treatment with peritoneal dialysis.

Design: Interventional study without control group.

Patients: Patients with chronic kidney disease over 18 years old, undergoing treatment with peritoneal dialysis for over 1 year; with reported diuresis of less than $100 \mathrm{ml}$ in 24 hours and in whom chronic idiopathic hypokalemia was diagnosed.
\end{abstract}

Materials and methods: All patients were tested for known causes of hypokalemia; once these causes were discarded we initiated treatment with spironolactone with an initial dose of $25 \mathrm{mgs}$ per day and a monthly increase of $25 \mathrm{mgs}$ until a maximum dose of $200 \mathrm{mg}$ per day. Serum potassium was measured monthly and dialyzed potassium was measured every 6 months.

Results: 20 patients fulfilled the requirements for inclusion. Four patients (20\%) developed hyperkalemia and had to stop the treatment. For the remaining 16 patients initial potassium of 2,84 was measured, 6 months later it was elevated to 3,40; 3,37 after 12 months; 3,58 after 18 months and 3,9 after 22 months, these values were statistically significant $(\mathrm{p}<0,05) .12$ episodes of peritonitis occurred for the 16 patients, representing an incidence of 1 episode per 19 patients month. The average dose of spironolactone used after 3 months was 65 mgs; $67 \mathrm{mgs}$ after 6 months; $75 \mathrm{mgs}$ after 12 months; $60 \mathrm{mgs}$ after 18 months and $68 \mathrm{mgs}$ after 22 months. In the 22 months follow up, $5(25 \%)$ patients were with drawn for motives not related to therapy and 7 of the $16(43.75 \%)$ patients passed away.

Conclusions: Hypokalemia is a cause of great mortality for patients undergoing treatment with peritoneal dialysis; in addition to its own risks it also facilitates the development of peritonitis that requires additional therapeutic interventions. We suggest that could Spironolactone diminish the intestinal loss of potassium but may cause hyperkalemia so patients must be closely monitored.

Key word: chronic kidney disease, peritoneal dialysis, and hypokalemia (fuente DeCS).

\section{Resultados del tratamiento de la hipopotasemia con espironolactona en paciente con enfermedad renal crónica en dialisis peritoneal}

\section{Resumen}

Objetivo: Determinar si el tratamiento con espironolactona puede corregir la hipopotasemia crónica idiopática de pacientes con enfermedad renal crónica (ERC) en tratamiento con diálisis peritoneal.

Diseño: Estudio de intervención sin grupo control. 
Pacientes: Pacientes con ERC mayores de 18 años, quienes requirieron diálisis peritoneal por más de 1, quienes tenían una diuresis menor a $100 \mathrm{ml} / 24$ horas, y en quienes se había diagnosticado hipopotasemia crónica idiopática.

Materiales y metodos: Todos los pacientes fueron valorados para causas conocidas de hipopotasemia. Una vez que fueron descartadas se optó por iniciar tratamiento con espironolactona, a una dosis inicial de 25 mgs por día e incrementos mensuales de $25 \mathrm{mgs}$, hasta una dosis máxima de $200 \mathrm{mgs}$. El potasio sérico fue medido cada mes y el potasio del dializado cada 6 meses.

Resultados: 20 pacientes cumplieron con los criterios de inclusión. 4 pacientes (20\%) desarrollaron hiperpotasemia y requirieron suspensión del tratamiento. Para el resto de los 16 pacientes el potasio inicial fue de 2,84 y 6 meses más tarde se elevó a 3,40; a los 12 meses su valor fue de 3,37, 3,58 a los 18 meses y 3,9 a los 22 meses, valores que fueron estadísticamente significativos $(\mathrm{p}<0,05)$. Se presentaron en el seguimiento de los 16 pacientes 12 episodios de peritonitis con una incidencia de 1 episodio por 19 pacientes mes. La dosis promedio de espironolactona utilizada fue de $65,67,75,60$ y 68 mgs para los meses $3,6,12,18$ y 22 , respectivamente, de seguimiento. 5 pacientes $(25 \%)$ fueron retirados del seguimiento por motivos no relacionados con la terapia y 7 pacientes $(43,75 \%)$ fallecieron.

Conclusiones: La hipopotasemia es causal de mortalidad en pacientes en tratamiento con diálisis peritoneal. Además su presencia es un factor de riesgo para la aparición de peritonitis, la cual requiere intervenciones adicionales. Nosotros sugerimos que la espironolactona puede disminuir las pérdidas intestinales de potasio, pero puede causar hiperpotasemia, siendo importante el seguimiento estrecho de los pacientes bajo tratamiento.

Palabras clave: Enfermedad renal crónica, diálisis peritoneal, hipopotasemia (MeSHsource).

\section{Introduction}

$\mathrm{H}$ ypokalemia is a complication rarely reported in patients with chronic kidney disease (CKD) although its prevalence can fluctuate between $10 \%$ through $36 \%$ in reports from several studies $^{1,2}$. Its etiology has been attributed to several different factors: some of them related to the underlying disease; others, to medical therapies, malnutrition and diets with low potassium intake ${ }^{3}$. Another explanation blames the transcelular distribution of potassium stimulated by insulin (in response to peritoneal glucose $)^{4}$, loss of potassium through urine, sweat and peritoneum specially when the number of exchanges is high and residual kidney function is presented ${ }^{5}$. In a few patients the etiology is idiopathic; we believe the intestinal loss of potassium may be an important cause due to the stimulation of the intestinal receptor by mineralocorticoid activity. It is our belief that blocking these receptors could prove beneficial for restoring the levels of potassium to normal.
This study describes our experience using spironolactone for the management of hypokalemia in chronic kidney disease patients undergoing peritoneal dialysis.

\section{Patients, materials and methods}

Patients with chronic kidney disease over 18 years old, undergoing treatment with peritoneal dialysis for over 1 year; with reported diuresis of less than $100 \mathrm{ml}$ in 24 hours and in whom chronic idiopathic hypokalemia (more than 4 months evolution) was diagnosed.

Hypokalemia was defined as values lower than $3,5 \mathrm{mEq} / \mathrm{L}$. Demographic variables were analyzed and all patients were evaluated for initial KT/V and Test of Peritoneal Equilibrium. These variables were also analyzed at the end of the study and the last registered value was used for the patients who passed away or were removed from treatment due to hyperkalemia or other reasons.

A high potassium intake diet was implemented in all patients; explainable causes of hypokalemia were 
discarded such as chronic diarrheal syndrome, repetition emesis, excessive sweating, excessive mineralocorticoids and the intake of medications than can cause hypokalemia (Diuretics, B2 adrenergics and xantines). We added an angiotensin converting enzyme inhibitor (ACE inhibitor) or an angiotensin II receptor antagonist (ARBs) to the treatment for all patients without low blood pressure values. Blood pressure was registered monthly and for its control in case high values were found an ACE inhibitor or an ARB was added in the first place, followed by a calcium channel blocker or an Alfa 1 antagonist depending on the treating doctors' judgment; the goal blood pressure was set around 140/90mmHg.

The levels for renin and aldosterone were determined for all patients as well as the dialyzed 24 hours potassium excretion. 24 hour potassium in urine was not determined due to the fact that all patients were anuric (diuresis less tan 100ml/24 hours); 24 hours fecal potassium was not determined either due to the difficulties at obtaining and processing the samples.

Patients received spironolactone with an initial dose of $25 \mathrm{mg}$ per day and a monthly increase of $25 \mathrm{mg}$ until a maximum dose of $200 \mathrm{mgs}$ per day. In case a potassium level was found higher than $4,5 \mathrm{meq} / \mathrm{L}$ the dose was reduced by $25 \mathrm{mgs}$; higher than $5,0 \mathrm{meq} / \mathrm{L}$ it was reduced by $50 \mathrm{mgs}$ and if it was found higher $\tan 5,5 \mathrm{meq} / \mathrm{L}$ the treatment was suspended. Serum potassium was measured monthly and dialyzed potassium was measured every 6 months. The study was extended for 22 months for the patients who achieved the time of evaluation, corresponding to the last cut of the research data.

\section{Design}

Interventional study without a control group. All patients gave their written consent before taking part in the study.

\section{Results}

20 patients met the inclusion criteria, $12(60 \%)$ in CAPD program and $8(40 \%)$ in APD. 4 men and 16 women with a mean age of: $65.7+/-9.08$, CKD etio- logy: 12 (60\%) diabetic nephropathy, 4 (20\%) hypertensive nephropathy, 4 (20\%) unknown etiology.

Four $(20 \%)$ patients required the discontinuation of therapy due to the appearance of hyperkalemia (mean plasma potassium at suspension of $5.905+/$ $0.34 \mathrm{mEq} / \mathrm{L}$ ) without clinical or electrocardiographic changes; all within the first 9 months of therapy and an average of 5.25 months; with an average dose of spironolactone at the time of suspension of $31.25+/-12.5 \mathrm{mg}$. Interestingly during the 14 months follow up of this group, no patient passed away or presented hypokalemia. The age of these patients was $65.25+/-8.42$ years, while the group that did not present $65.81+/-9.50$ without statistically significant differences.

Of $16(80 \%)$ patients who did not develop hyperkalemia, eleven completed 6 months follow-up, 8 twelve months, six 17 months, and only four patients 22 months.

5 patients were withdrawn for reasons unrelated to therapy: two were transferred to a different health institution, one underwent renal transplant, one had a recovering residual renal function and one was transferred to hemodialysis due to refractory peritonitis. 7 of the $16(43.75 \%)$ patients passed away during follow-up; their average serum potassium at the time of death was $3.06+/-0.70 .2$ within the first 4 months of starting treatment; the causes of death were: 1 myocardial infarction and 1 pneumonia; the remaining 5 patients passed away between three and seven months of treatment; one at 11 months and the last at 16 months. The causes of death were: 2 hemorrhagic strokes, 2 lower limb gangrene, and one sudden death.

Only 3 patients' had initial potassium values higher than $30 \mathrm{mEq}$ in 24 hours dialysate; two of them passed away in the first 6 months follow-up. The remaining patient had a potassium dialysate of 31.58 at 6 months treatment; 35.88 at 12 months; 43.74 at 18 months and 15.7 at 22 months. The 24 hours dialysate potassium was found at an average of $26.78+/$ 15.22 for all patients; an average of $26.40+/-16.17$ for the patients who didn't develop hyperkalemia, and an average of $28.32+/-12.78$ for the ones who did present it. At 6 months follow up this value was 
$32.51+/-10.82$ for all patients; $30.19+/-10.63$ for the group without hyperkalemia and an elevation was found in the hyperkalemia group with an average of $42.92+/-2.90$. This probably reflected serum potassium and indicated dialysate independent factors in the generation of changes in serum potassium. The 12 month follow up values for the group without hyperkalemia were averages of: $22.51+/$ 5.44 at 12 months; $30.91+/-12.87$ at 18 months and $29.93+/-18.48$ at 22 months.

The initial serum albumin was evaluated for an average of $3.15+/-0.39$ for all patients; for deceased patients an average of $2.99+/-0.51$ and for non deceased patients an average of (13) $3.25+/-0.30$. Of the 7 patients who passed away six $(85.71 \%)$ had low albumin values at baseline. The initial serum albumin for patients who developed hyperkalemia during treatment was an average of $3.45+/-0.05$ and for those who didn't it was an average of $3.09+/-$ 0.41.In the group of patients with improvement in the value of serum potassium, serum albumin from an initial value of $3.09+/-0.41$ shifts to a final value of $3.09+/-0.54$ statistically unchanged significant.
The total values of renin before treatment averaged $22.33 \mathrm{pg} / \mathrm{ml}$; the total values for aldosterone averaged $6.51 \mathrm{ng} / 100 \mathrm{cc}$. No patient presented renin values greater than $65 \mathrm{pg} / \mathrm{ml}$; or aldosterone values greater than $20 \mathrm{ng} / 100 \mathrm{cc}$ compatible with mineralocorticoid excess.

12 episodes of peritonitis occurred in 16 patients, representing an incidence of 1 episode per 19 patients month; in comparison with the total group of patients (136 on average) evaluated in the same time period and with a calculated incidence of 1 episode per 44 patients month.

The initial potassium for the 16 patients who didn't develop hyperkalemia was 2.84 ; at 6 months it was raised to 3.40 ; at 12 months $3.37 ; 18$ months 3.58 and at 22 months it was 3.9 (Figure 1). The average dose of spironolactone used at 3 months was 65 mgs; 67 mgs at 6 months; 75 mgs at 12 months; 60 mgs at 18 months, $68 \mathrm{mgs}$ at 22 months.

In order to the determine the behavior of serum potassium in the patients enrolled in the study we used the following procedure. Patients who could recei-

Figure 1.

Evolution of serum potassium in time

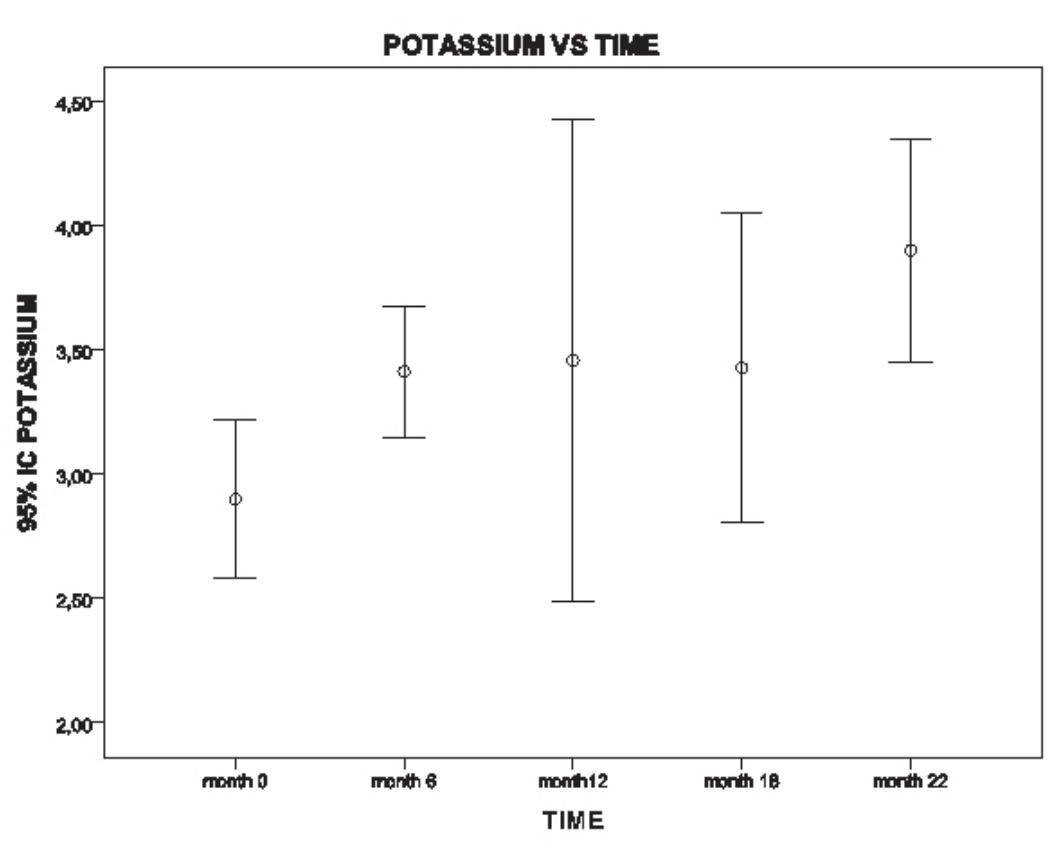


ve the 5 measurements (4 patients) were selected and their mean result was obtained for each period: month 0 , month 6 , month 12 , month 18 , and month 22 (Table 1). When Applying the Normality test we found that at month 0 the distribution did not behave normally $\mathrm{P}<0.05$; therefore in order to demonstrate statistical significance the nonparametric Kruskal-Wallis test was applied. Significant differences were found $(p=0,034)$ in the values of serum potassium comparing the 5 period controls of the patients who ended the process (Table 2,3). Analyzing the measurements in the graph, note that at month 0 they present the lowest average levels and is the period that marks the difference compared with the measurement at month 22 .

The value for initial KT/V was an average of 1.76 $+/-0.67$ for all patients,with an average age of 65.7 $+/-9.08$ and at the end it was $1.79+/-0.40$. The peri-

\begin{tabular}{|llc|}
\hline \multicolumn{3}{|c|}{ Table 1. } \\
\hline \multicolumn{3}{|c|}{ Mean Serum potassium in patients who completed } \\
the process \\
\hline Time & Mean & Standard Deviation \\
\hline month 0 & 2,9000 &, 20000 \\
month 6 & 3,4125 &, 16520 \\
month 12 & 3,4575 &, 61092 \\
month 18 & 3,4275 &, 38948 \\
month 22 & 3,9000 &, 28284 \\
Total & 3,4195 &, 4631 \\
\hline
\end{tabular}

toneal equilibrium test was evaluated in the group of patients who did not develop hyperkalemia; 6 were found to be low transporters of glucose; 9 were high transporters of glucose; 6 were low transporters of creatinine and 9 were high transporters of creatinine. Evaluating these parameters at the end of the study we found no significant changes.

Evaluating the blood pressure variable we realized it was elevated in both groups with and without hyperkalemia but we decided not to consider it as an important variable because we allowed changes in antihypertensive therapy for patients with high cardiovascular risk. None of the side effects for spironolactone were observed such as gynecomasty and low blood pressure.

\section{Discussion}

Hypokalemia is a rare complication in CKD patients but it is associated with significant complications with increased morbidity and mortality ${ }^{1,3,6}$ even though all-cause and cardiovascular mortality can be higher in the first year of peritoneal dialysis ${ }^{7}$.

Hypokalemia is also considered a risk factor for peritonitis in patients undergoing peritoneal dialysis ${ }^{8,9}$. It could be caused by a reduction in gastrointestinal motility, with subsequent bacterial overgrowth and trans mural migration of enteric organisms ${ }^{10}$. It could also be a marker of malnutrition, relating to alterations in the immune defense mechanisms ${ }^{1,11}$.

Due to the risk that hypokalemia represents, it's treatment is paramount. Various therapies have

\begin{tabular}{|c|c|c|c|c|c|c|c|}
\hline \multicolumn{8}{|c|}{ Table 2.} \\
\hline \multicolumn{8}{|c|}{ Normality test } \\
\hline \multirow{2}{*}{ POTASSIUM } & \multirow{2}{*}{ TIME } & \multicolumn{3}{|c|}{ Kolmogorov-Smirnov(a) } & \multicolumn{3}{|c|}{ Shapiro-Wilk } \\
\hline & & Statistic & gl & Sig. & Statistic & gl & Sig. \\
\hline & month 0 & ,441 & 4 & & ,630 & 4 &, 001 \\
\hline & month 6 &, 252 & 4 & & ,916 & 4 &, 513 \\
\hline & month 12 &, 278 & 4 & & ,942 & 4 & ,666 \\
\hline & month 18 &, 258 & 4 & . & ,900 & 4 & ,429 \\
\hline & month 22 & ,260 & 4 & & ,827 & 4 & 161 \\
\hline
\end{tabular}




\begin{tabular}{|c|c|}
\hline \multicolumn{2}{|c|}{ Table 3.} \\
\hline \multicolumn{2}{|c|}{ Contrast Statistic $(a, b)$} \\
\hline \multicolumn{2}{|c|}{ ContrastStatistic(a,b) } \\
\hline & POTASSIUM \\
\hline Chi-square & 10,429 \\
\hline & 4 \\
\hline Sig. asintót. & ,034 \\
\hline $\begin{array}{l}\text { aKruskal-W: } \\
\text { b Aggregatic }\end{array}$ & \\
\hline
\end{tabular}

been tried; including increased oral intake of potassium $^{2}, 12$; Icodextrin to improve nutritional status, and generate lower insulin secretion ${ }^{13,14}$; potassium infusion in the bags for dialysis ${ }^{15-17}$ and mineralocorticoid blockade with mineralocorticoid receptor antagonists (MRAs).

Mineralocorticoid blockade has always been considered high risk in patients with CKD; it has been used in patients with CKD and resistant hypertension. In a group of patients without dialysis Pisoni et al obtained therapeutic efficacy, but with the risk of generating hyperkalemia, and a fall in the GFR ${ }^{18}$. In patients undergoing dialysis therapy, Xiaoying Ni et al achieved a significant reduction in blood pressure, but 2 patients required the discontinuation of medication by the development of hyperkalemia ${ }^{19}$.

In the Dialysis Outcome Heart Failure Aldactone Study (DOHAS), Matsumoto Y, et al in patients undergoing hemodialysis, spironolactone reduced the frequency of death or hospitalization for cardio-cerebrovascular events and hyperkalemia was observed only in $1.9 \%$ of patients ${ }^{20}$.

In patients undergoing peritoneal dialysis with Class III and IV heart failure, the spirono lactone improvement the patients' ejection fraction, and left ventricle mass index with very low side effects such as hyperkalemia, only in one patient in the study of Taheri et $\mathrm{al}^{21}$, and 2 in the Ito $\mathrm{Y}$ et $\mathrm{al}^{22}$.

Yongsiri $\mathrm{S}$ et al, in a randomized, double-blind, placebo controlled trial conducted in 24 peritoneal dialysis patients with hypokalemia, evaluated the therapeutic response to $25 \mathrm{mgs}$ of spironolactone for 4 weeks. They found no significant changes in serum potassium; however they did not increase the dose and the study was conducted for a very short time ${ }^{23}$.

In our study we found that hypoalbuminemia is common in patients who were diagnosed with hypokalemia, their presence is linked with high mortality and the possible emergence of bacterial peritonitis. The absence of significant variation in the values of serum albumin between its initial and final value excludes improvement of nutritional status that explains the rise in serum potassium.

Treatment with spironolactone can correct hypokalemia, but patients must be closely monitored due to the risk of hyperkalemia, especially in anuric patients. The age of patients with treatment in the group of hyperkalemia was not different that group without hyperkalemia, important aspect because the aged patients have major possibility of this complication ${ }^{24}$. The KT/V and age of the patients at the beginning and end of treatment was found in the recommended goals, being unlikely to contribute to potassium disturbances, their correction, and the appearance of hyperkalemia.

We suggest that hypokalemic CKD patients undergoing peritoneal dialysis may have an abnormal activity in the colon's aldosterone-sensitive epithelial sodium channels, which could result in sodium retention and increased potassium loss by digestive tract. We believe that the administration of an aldosterone antagonist (spironolactone) could reduce their losses and restore serum potassium levels.

It has been observed that the aldosterone levels in CKD patients rise gradually when their GFR is less than $50 \mathrm{ml} /$ minute. The intestinal cells of the colon and small intestine may be affected by aldosterone effect, with an increase in luminal membrane permeability to sodium and a subsequent activation of new sodium channels, resulting in an increased activity and number of Na,K-ATPase pumps. The result of the above interaction is intestinal sodium retention and increased intestinal potassium $\operatorname{loss}^{25}$. 
It is also likely that low sodium intake diets common in CKD patients undergoing dialysis therapy may reactively decrease the levels of protein type 2 11B-hydroxysteroid dehydrogenase (11 B-HSD2) in the colon; this protein degrades cortisol to cortisone, a metabolite without sodium retaining activity. Subsequently an elevation of messenger RNA levels occurs and an increased activity of the epithelial sodium channel $(\mathrm{ENaC})$; this condition is mediated by the activation of the mineralocorticoid receptor $^{26}$.

In support of our suggestions there are studies that have shown that sodium reabsorption is an active process that occurs in the rectum and colon muco$\mathrm{sa}^{27,28}$. This process is regulated at least in part by the mineralocorticoid receptor ${ }^{29}$ and results in the activation of the epithelial sodium channels ${ }^{30}$. Mineralocorticoid receptor activation by fludrocortisone increases the rectal electrical potential difference, an effect that is also achieved by inhibiting the enzyme $11 \mathrm{~B}-\mathrm{HSD} 2$ in rectal segments obtained from a human colon ${ }^{31}$.

The relevance of extra renal 11 B-HSD2 enzymes in humans has been demonstrated in patients without renal function, in which the glycyrrhetinic acid has significantly decreased the levels of plasma potassium ${ }^{32}$. Colon sodium absorption in experimental models of chronic renal failure with the $5 / 6$ nephrectomy, increases as the GFR is reduced, accompanied by elevated expression of $\mathrm{ENaC}$, an effect that may be partially mediated by the AT1 receptor agonist ${ }^{33}$.

\section{Conclusions}

Hypokalemia is a cause of great mortality for patients undergoing treatment with peritoneal dialysis; in addition to its own risks it also facilitates the development of peritonitis that requires additional therapeutic interventions. We suggest that the Spironolactone could to correct hypokalemia at diminish the intestinal loss of potassium, but may cause hyperkalemia so patients must be closely monitored. Preventing malnutrition and avoiding very low sodium intake diets may contribute to prevent hypokalemia.

It is necessary to design studio in which can reliably measure fecal excretion of potassium, and thus confirm our suggestion.

\section{Compliance with ethical standards}

The authors state that the study was not funded. None of the authors received research grants from company or speaker honorarium from company. None of the authors is a member of committees, and declare they have no conflicts of interest.

The study met all standards of the institutional and / or national research ethical committee, and with the 1964 Helsinki declaration and its later Amendments or comparable ethical standards.

Informed consent was obtained from all single participants included in the study.

\section{Conflict of interests}

The authors declare no conflicts of interest of any kind.

\section{Bibliographic references}

1. Szeto CC, Chow KM, Kwan BC, Leung CB, Chung KY, Law MC, et al. Hypokalemia en Chinese peritoneal dialysis patients: prevalence and prognostic implication. Am J Kidney Dis. 2005;46:128-135.

2. Khan AN, Bernardini J, Johnston JR, Piraino B. Hypokalemia in peritoneal dialysis patients. Perit Dial Int. 1996;16:652.

3. Vavruk AM, Martins C, Nascimento MM, Hayashi SY, Riella MC. Association between hypokalemia, malnutrition and mortality in peritoneal dialysis patients. J Bras Nefrol. 2012;34:349-354.

4. Tziviskou E, Musso C, Bellizzi V, Khandelwal M, Wang T, Savaj S, et al. Prevalence and pathogenesis of Hypokalemia in patients on chronic peritoneal dialysis: one center's experience and review of the literature. Int Urol Nephrol. 2003;35:429-434. 
5. Yu HL, Lu XH, Su CY, Tang W, Wang T. Potassium metabolism in continuous ambulatory peritoneal dialysis patients. Ren Fail. 2014;36:748-754.

6. Torlen K, Kalantar-Zadeh K, Molnar MZ, Vashistha T, Mehrotra R. Serum potassium and cause specific mortality in a large peritoneal dialysis cohort. Clin J Am Soc Nephrol. 2012;7:1272-1284.

7. Xu Q, Xu F, Fan L, Xiong L, Li H, Cao S, et al. Serum potassium levels and its variability in incident peritoneal dialysis patients: associations with mortality. Plos One. 2014;9: e86750.

8. Chuang YW, Shu KH, Yu TM, Cheng CH, Chen CH. Hypokalaemia: an independent risk factor of Enterobacteriaceae peritonitis en CAPD patients. Nephrol Dial Transplant. 2009;24:1603-1608.

9. Liawnoraset W. Prevalence and factors affecting peritonitis in CAPD in Mahart Nakhon Ratchasima Hospital under universal coverage scheme during 2008-2010: a three year experience. J Med Assoc Thai. 2011;94 Suppl 4:S19-S24.

10. Shu KH, Chang CS, Chuang YW, Cheng CH, Wu MJ, Yu TM. Intestinal bacterial overgrowth in CAPD patients with hypokalaemia. Nephrol Dial Transplant. 2009;24:1289-1292.

11. Jung JY, Chang JH, Lee HH, Chung W, Kim S. De novo hypokalemia in incident peritoneal dialysis patients: a year observational study. Electrolyte Blood Press. 2009;7:73-78.

12. Factor KF. Potassium management in pediatric peritoneal dialysis patients: can diet with increased potassium maintain a normal serum potassium without a potassium supplement? Adv Perit Dial 2007;23:167-169.

13. Yi JH, Yun YW, Han SW, Kim HJ. Comparison of Icodextrin and 2,5\% glucose in potassium metabolism by acute K load via dialysate in continuous ambulatory peritoneal dialysis patients. Electrolyte Blood Press. 2009;7:25-30.

14. Yi JH, Park JI, Choi HY, Lee HY, Han SW, Kim HJ. Icodextrin improves the serum potassium profile with enhancement of nutritional status in continuous ambulatory peritoneal dialysis patients. Electrolyte Blood Press. 2009;7:7986.

15. Spital A, Sterns RH. Potassium supplementation via the dialysate in continuous ambulatory peritoneal dialysis. Am J Kidney Dis. 1985;6:173-176.

16. Amirmokri P, Morgan P, Bastani B. Intra-peritoneal administration of potassium and magnesium: A practical method to supplement these electrolytes in peritoneal dialysis. Ren Fail. 2007;29:603-605.

17. Rostand SG. Profound hypokalemia in continuous ambulatory peritoneal dialysis. Arch Intern Med. 1983;143:377378.

18. Pisoni R, Acelejado MC, Cartmill FR, Dudenbostel T, Dellítalia LJ, Cofield SS, et al. Long term effects of aldosterone blockade en resistant hypertension associated with chronic kidney disease. Journal of Human Hypertension. 2012;26: 502-506.

19. Ni X, Zhang J, Zhang P, Wu F, Xia M, Ying G,Chen J. Effects of spironolactone on dialysis patients with refractory hypertesion. J Clin Hypertens (Greenwich). 2014:1-6.

20. Matsumoto Y, Mori Y, Kageyama S, Arihara K, Sugiyama T, Ohmura H, Yakushigawa T, Sugiyama H, Shimada Y, Nojima Y, Shio N. Spironolactone reduces cardiovascular and cerebrovascular morbidity and mortality in hemodialysis patients. JACC. 2014;63:528-536.

21. Taheri S, Mortazavi M, Pourmoghadas A, Seyrafian S, Alipour Z, Karimi S. A prospective double blind randomized placebo controlled clinical trial to evaluate the safety and efficacy of spironolactone in patients with advanced congestive heart failure on continuous ambulatory peritoneal dialysis. Saudy J Kidney Dis Transplant. 2012;23:507-512.

22. Ito Y, Mizuno M, Suzuki Y, Tamai H, Hiramatsu T, Ohashi H, et al. Nagoya Spiro Study Group. Long-term effects of spironolactone in peritoneal dialysis patients. J Am Soc Nephrol. 2014;251094-102.

23. Yongsiri S, Thammakumpee J, Prongnamchai S, Tengpraettanakorn P, Chueansuwan R, Tangjaturonrasme S, et al. Randomized, Double-Blind, Placebo-Controlled Trial of Spironolactone for Hypokalemia in Continuous Ambulatory Peritoneal Dialysis Patients. Ther Apher Dial. 2014 Sep 4. doi: 10.1111/1744-9987.12219. [Epub ahead of print].

24. Musso CG, de Miguel R, Algranati L, Dos Ramos Farias E. Renal potassium excretion: Comparison between chronic renal disease patients and old people. Int Urol Nephrol. 2005;37:167-170. 
25. Musso CG. Potassium metabolism in patients with chronic kidney disease (CKD), part I: patients not on dialysis (stages 3-4). Int Urol Nephrol. 2004;36:465-468.

26. Diaz IH, Giraldez T, Morales S, Hernandez G, Salido E, Canessa CM, et al. Heterogeneous nuclear ribonucleoprotein A2/B1 is a tissue specific aldosterone target gene with prominent induction in the rat distal colon. Am J Physiol Gastrointest Liver Physiol. 2012;304:G122-G131.

27. Tomkins AM, Edmonds CJ. Electrical potential difference, sodium absorption and potassium secretion by the human rectum during carbenoxolone therapy. Gut. 1975;16:277-284.

28. Turnamian SG, Binder HJ. Regulation of active sodium and potassium transport in the distal colon of the rat. Role of the aldosterone and glucocorticoid receptors. J Clin Invest. 1989;84:1924-1929.

29. Cho JH, Musch MW, Bookstein CM, McSwine RL, Rabenau K, Chang EB. Aldosterone stimulates intestinal Na+ absorption in rats by increasing NHE3 expression of the proximal colon. Am J Physiol Cell Physiol. 1998;274: C586-C594.

30. Bergann T, Plöger S, Fromm A, Zeissig S, Borden SA, Fromm M, et al. A colonic mineralocorticoid receptor cell model expressing epithelial Na+ channels. Biochem Biophys Res Commun. 2009;382:280-285.

31. Epple HJ, Schulzke JD, Schmitz H, Fromm M. Enzyme- and mineralocorticoid receptor-controlled electrogenic Na+ absorption in human rectum in vitro. Am J Physiol. 1995;269:G42-G48.

32. Farese S, Kruse A, Pasch A, Dick B, Frey BM, Uehlinger DE, Frey FJ. Glycyrrhetinic acid food supplementation lowers serum potassium concentration in chronic hemodialysis patients. Kidney Int. 2009;76:877-884.

33. Hatch M, Freel RW. Increased colonic sodium absorption in rats with chronic renal failure is partially mediated by AT1 receptor agonism. Am J Physiol Gastrointest Liver Physiol. 2008; 295:G348-G356. 